\title{
THE IDEA OF MODIFICATION OF WORK CONDITIONS FOR THE REDUCTION OF THE PILOT'S WORKLOAD IN A GLIDER, TYPE SZD-30
}

\section{KONCEPCJA MODYFIKACJI WARUNKÓW PRACY ZMNIEJSZAJĄCYCH OBCIĄŻENIA PILOTA SZYBOWCA TYPU SZD-30}

\author{
Marcin Berlik, Grzegorz Dahlke, Małgorzata Slawińska
}

Politechnika Poznańska, Wydział Inżynierii Zarządzania

Poznań University of Technology, Faculty of Engineering Management

\begin{abstract}
The paper presents a method for identifying the risk of disorders in the muscular and skeleton system, which would enable an assessment of the load of the motoric system that constitute one of important aspect for ergonomic risk. The result of the research made with use of the RULA method confirms the necessity of an urgent implementation of correcting actions aimed at improving the ergonomics of the pilot's cabin. Some of them are difficult to put into practice in view to their high costs. One should also remember that the exploitation period is nearly expired so the implementation of improvements does not make much sense. However, there is a possibility of implementing many modifications that do not require high costs and that do not affect significantly the construction of the glider.
\end{abstract}

Keywords: workload of a pilot, disorders in the muscular and skeleton system, reliability of a pilot

Streszczenie: $W$ artykule przedstawiona została metoda identyfikacji narażenia na dolegliwości układu mięśniowo - szkieletowego, która umożliwia ocenę obciążeń układu ruchu stanowiących jeden $z$ aspektów ryzyka ergonomicznego. Wyniki oceny metoda RULA świadcza o konieczności pilnego przeprowadzenia zmian. W artykule podano różne propozycje działań korygujących, mających na celu poprawę ergonomiczności kabiny szybowca. Niektóre z nich sa trudne do wdrożenia ze względu na duże koszty oraz fakt, iż znacząca część planowanego okresu eksploatacji już uptynęła. Istnieje natomiast możliwość wprowadzania wielu modyfikacji, które nie pociagaja za soba wysokich kosztów oraz nie ingeruja w sposób znaczacy w konstrukcję szybowca.

Stowa kluczowe: obciążenie pilota, dolegliwości układu mięśniowo szkieletowego, niezawodność pilota 
The idea of modification of work conditions for the reduction of the pilot's...

Koncepcja modyfikacji warunków pracy zmniejszajacych obciażenia pilota...

\section{THE IDEA OF MODIFICATION OF WORK CONDITIONS FOR THE REDUCTION OF THE PILOT'S WORKLOAD IN A GLIDER, TYPE SZD-30}

\section{Introduction}

Designing workstations with the use of knowledge on psycho-physical abilities of a man contributes to the reduction of the risk for occurring work task overloads, like for example ailments of the motoric system of the worker that might cause the decrease of the reliability in performing work tasks and growing risk of accidents.

The position, in which the employee stays during his work can affect the appearance of accidents or symptoms of diseases of the motoric system [1], [2].

One can enumerate following factors of the ergonomic risk that generate ailments of the motoric system:

- the work the requires staying in an extorted position,

- the work that requires frequent lifting, pushing, pulling or other manual effort for moving heavy objects,

- long-lasting, repeating, significant effort of hands,

- exposure to vibrations,

- exposure to cold [1].

It is important the design the technique in an aware way, taking under consideration factors mentioned before, so that man would be exposed to the smallest load possible. A glider, type SZD-30 "Pirat" was established as the object of technical use, with consideration of the position of the operator's body and in view to the group of important factors of the overload. The researcher knows from his personal experience, supported by observations, that the work of a pilot requires a very high concentration, agility of attention, ability to control many parameters at the same time, making decisions fast and precise operating with the steering system. All these elements constitute a so-called system-load [1], [3], [4]. The way of using technical devices is strongly determined by the construction of technical elements.

The glider, type SZD-30 "Pirat" is a one-seat wooden glider in the high-wing system. The construction was designed in the 70-ies of the twentieth century. The idea of its producer was to offer a temporary reinforcement of the fleet of the Polish Aero-club. However, it still remains one of basic gliders for training of pilots with less experience in long thermal flights and for making first attempts of flights [5].

Trainers perceive the "Pirat" as a dangerous glider, view to its problems on the field of ergonomics.

The State Commission on Aircraft Accidents Investigation presents problems of ergonomics of this glider in its final conclusion for reports on accidents and incidents as one of major causes of such events.

Its reports that main problems result from disproportion of strength that occurs in helms (each helm requires a different force for tilting a helm surface for a determined value), alike the proportions for tilting (for example the tilting of the aileron generates a certain angular velocity for the change of the tilt, while the same tilt of the rudder of the height onto the sticks generates a much higher angular velocity of the change of tilt). 
Moreover, the aerodynamic brake lever faces very strong forces that often hamper closing them (especially if the pilot didn't have much physical strength). Putting much effort on the lifted helm might have influence on placing the brake, as well as on the form of the lever. These three disadvantages are mentioned in the Flight Manual. Unfortunately, there hasn't been introduced any modification that would significantly reduce these inconveniences [6].



Pic. 1 The insight of the cabin of the glider SZD-30 „Pirat” during the flight (Source: own photography).

The unnatural body position has much influence on the feeling of tiredness, on the quality of operation performed by the commander of the flying unit, as well as on the correct work on helms. The present paper focuses on the examination of the ergonomic risk of the pilot of such type of glider.

\section{Assessment of the ergonomic risk}

There are many methods for assessing the risk. They differ by the level of their complexity and possibility of their application. The choice of the method is very important. Here are most frequently used methods for identification of biomechanic factors of risk [7]:

- surveys and interviews with employees,

- audits,

- expert control methods,

- analytic methods of measurements based on observation (direct and indirect),

- direct measurements of mechanical stress,

- creating models (based on experiences or theoretical and experimental).

Rapid Upper Limb Assessment (RULA) is a method for measuring a postural and operational load for upper limbs that occurs while performing activities in a sitting position. It allows assessing the risk of the occurrence of ailments and diseases of the motor system as result of the performed work. 
The idea of modification of work conditions for the reduction of the pilot's... Koncepcja modyfikacji warunków pracy zmniejszajacych obciażenia pilota...

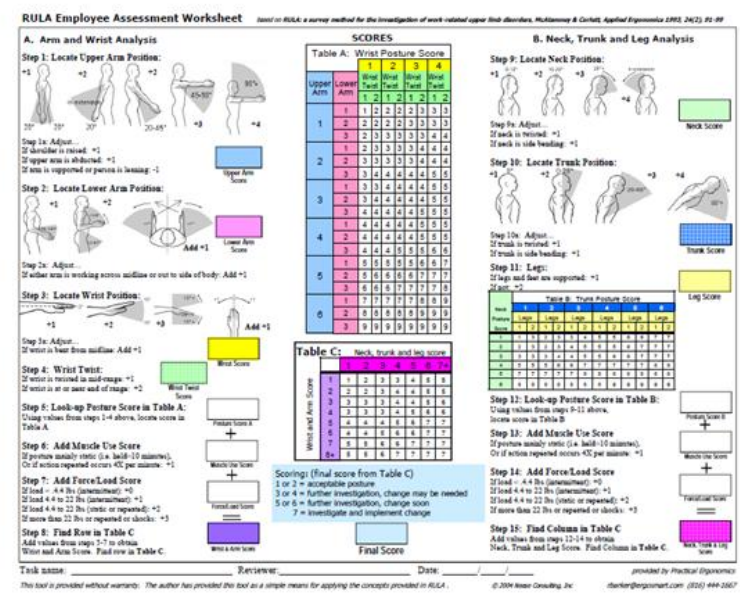

Fig. 1 Questionnaire for the method RULA [9].

This method can be used in the process of the ergonomic design and during the ergonomic correction of the workstation, within the range of applied forces, the position and the external load [7], [8]. The RULA method allows:

- identification and assessment of ergonomic factors for the occurrence of MSDs in a relatively short time,

- determining directions for the ergonomic intervention,

- the assessment of the load of the muscular and skeleton system with work, in view to individual tasks and operations.

\section{The characteristic of an aircraft [10]}

Examinations were made on a glider SZD-30 "Pirat", signed SP-2741, which was used in the Central Glider School of the Polish Air-club in Leszno.

The glider SZD-30 "Pirat" is a one-seat training glider. At first it was allowed to be used for acrobatic figures.

The cabin gives enough space for a comfort of one pilot of no more than $2 \mathrm{~m}$ height, with a parachute. Before sitting in the cabin, the pilot has to set the backrest for the parachute. The setting of pedals can be changed before the flight, but also during it. The pilot is fastened with stripes, he should have the ability to make full tilts of the sticker and the pedals, as well as have a free reach of his hands onto the control panel.

\section{Results of the examination made with use of the RULA method}

The RULA method is for measuring the postural and operational load of the upper limbs that might occur during operations in a sitting position. It allows assessing the risk for ailments and diseases of the motor system resulting from the method of the performed work [8].

During the flight in a glider, the pilot performs many operations that have a strong affect on the safety of the flight operation. The performance of each activity causes a change of the pilot's position, which affects the change of the load of the muscular and skeleton system. Examinations performed in the pilot's cabin included the study of 15 activities performed by the pilot with his left and right hand during the flight. Chosen movements are presented in the table 1 . 
Marcin Berlik, Grzegorz Dahlke, Małgorzata Stawińska

Tab. 1 Set of chosen activities performed by the pilot of the glider examined in the analysis (Source: personal elaboration, author's photographs).

\begin{tabular}{|c|c|c|c|}
\hline No. & $\begin{array}{l}\text { Name of the } \\
\text { activity performed } \\
\text { by the pilot }\end{array}$ & $\begin{array}{c}\text { View } 1 \\
\text { (on the side) }\end{array}$ & $\begin{array}{l}\text { View } 2 \\
\text { (on the top) }\end{array}$ \\
\hline 1 & $\begin{array}{c}\text { Height control } \\
\text { "ousted", ailerons } \\
\text { left }\end{array}$ & & \\
\hline 2 & $\begin{array}{l}\text { Height control } \\
\text { "zoomed", ailerons } \\
\text { left }\end{array}$ & & \\
\hline 3 & $\begin{array}{l}\text { Height control } \\
\text { "zoomed", ailerons } \\
\text { right }\end{array}$ & & \\
\hline 4 & $\begin{array}{c}\text { Open aerodynamic } \\
\text { brakes }\end{array}$ & & \\
\hline 5 & $\begin{array}{l}\text { Trimmer "load on } \\
\text { the back" }\end{array}$ & & \\
\hline 6 & $\begin{array}{l}\text { Neutral position } \\
\text { (neutral position of } \\
\text { controls, left hand } \\
\text { on the knee - } \\
\text { standby position) }\end{array}$ & & \\
\hline
\end{tabular}


The idea of modification of work conditions for the reduction of the pilot's... Koncepcja modyfikacji warunków pracy zmniejszajacych obciażenia pilota...

Tab. 2 Set of final assessments according to the RULA method for examined activities (Source: personal elaboration)

\begin{tabular}{|c|l|c|}
\hline No. & \multicolumn{1}{|c|}{ Activity } & $\begin{array}{c}\text { Final } \\
\text { assessment } \\
\text { according to } \\
\text { RULA }\end{array}$ \\
\hline 1 & Neutral position & 4 \\
\hline 2 & Release the rope & 4 \\
\hline 3 & Height control "ousted", neutral ailerons & 4 \\
\hline 4 & ailerons left, neutral height control & 4 \\
\hline 5 & ailerons right, neutral height control & 5 \\
\hline 6 & Height control "ousted", ailerons left & 5 \\
\hline 7 & Height control "ousted", ailerons right & 4 \\
\hline 8 & Height control "zoomed", ailerons left & 6 \\
\hline 9 & Height control "zoomed", ailerons right & 6 \\
\hline 10 & Closed aerodynamic brakes & 6 \\
\hline 11 & Open aerodynamic brakes & 6 \\
\hline 12 & Trimmer "load on the front" & 5 \\
\hline 13 & Trimmer "load on the back" & 5 \\
\hline 14 & Operation of the radio station & 5 \\
\hline 15 & Operation of the ventilator & \\
\hline
\end{tabular}

Tab. 3 Assessment scale for the RULA method

\begin{tabular}{|c|c|c|c|c|c|c|}
\hline \multicolumn{7}{|c|}{ Assessment scale for the RULA method } \\
\hline 1 & 2 & 3 & 4 & 5 & 6 & 7 \\
\hline & & & & & & 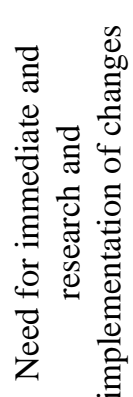 \\
\hline
\end{tabular}


Results for examined 15 activities vary within the range from 4 to 6 . A relatively low range of value is a result of the fact that the pilot in the cabin has a strongly immobile corpus (fastened with seatbelts on the level of his chest and hips) that strongly determinates the immobility of the neck and the head. The most of changes of positions refers to arms, forearms and wrists; they cannot change assessments in a significant way. Values from 4 to 6 are high and they should sharpen the attention of every auditor.

In case of five activities the assessment was 4 . This means that it is necessary to conduce more accurate examination and that it is possible that there will appear a necessity of implementing changes. These are activities approximate to the neutral position (neutral control, left hand on the knee). Placing the hand on the knee in the neutral position is not resulting from the pilot's comfort and it is trained during the entire process of training. It supposed to give an easy and fast access to all controls and hamper an accidental movement of any of steering controls in case of any acceleration affecting the glider on any direction. Such situations take place in case of a frequent practice of keeping the hand on the brake control stick, which is incorrect. The lowest result for this position may confirm that the most difficult positions of control sticks are the extreme ones, in all directions (both in cases when they are close or far from the pilot).

The result of the RULA method is equal for 5 activities. It confirms that there is an urgent necessity to conduce more detailed examinations and implementing changes. For the use of the trimmer, the higher value results from the necessity of simultaneous banding and twisting the wrist. In this case the most simple solution would be to modify shape of the handle for making the grip easier, for example by giving it an oblong shape that runs vertically downwards. This would avoid difficulties in entering into the cabin of the glider and getting out of it, especially in emergency situations. Activities connected to the service of the radio station and the ventilator also obtained the result 5 . This result was caused by twisting and banding of the wrist caused by the arrangement of the manipulator of the radio station and the ventilator aside from the axe of the stretched arm of the pilot (this refers especially to the use of the ventilator, for which the control must be moved on the line of 45 degrees to the axe of the arm). The remaining two results of 5 points for activities "Height control "ousted", ailerons left" and "ailerons right, neutral height control" result mostly from the transfer of the force during the operation of tilting the aileron. These are the lowest assessments for activities with tilting ailerons. This results mostly from the fact that during these activities the control is in a position that doesn't require bending or twisting the wrist.

The highest result -6 points, was assigned to 4 positions. This confirms that there is an urgent necessity of conducing accurate examinations and implementing changes. This result is very high. There are two main causes of accepting so high values in these parts of the assessment. In case of the operation "Height control "zoomed", ailerons left" and "Height control "zoomed", ailerons right" one could observe strong bending and twisting.

It resulted from bringing the control extremely close to the pilot's corpus. On the right the control must be very close to the pilot's hip. In case of a limited space (the pilot cannot withdraw his arm) this requires bending and twisting the wrist. 
The idea of modification of work conditions for the reduction of the pilot's... Koncepcja modyfikacji warunków pracy zmniejszajacych obciażenia pilota...

On the left the pilot is forced to put the control stick by his left hip, so he must bring his upper limb to the torso, bend his forearm, his wrist and twist them (many pilots with more weight or with warmer clothes is forced to bypass their bellies and seatbelts and this generates even more difficulties because they must bent their limbs even more into unnatural positions). The majority of pilots face the problem of difficulty with obtaining a full tilt "zoom in" and to the sides, not only because of low abilities of their upper limbs, but also because controllers are blocked by their legs. Presented problems confirm that the controller is placed too close to the pilot. In the same time this localization is necessary for putting the controller on both left and right sides and to the front. It is possible to solve this problem by making the controller shorter (which would require reducing forces affecting it by redesigning the gear on ailerons and the height control).

The result 6 was also obtained for positions related to the service of the aerodynamic brake. In this case the factor affecting the result was the high force necessary for the manipulation of this controller. Keeping the brake in a required position, if it is not blocked, requires a significant effort. It is cause by the effect of "sucking out" the aerodynamic brake from the wing and this force is transferred with the mechanism of the brake into the controller in the cabin. The most important operation for improving it would be reducing the force that occurs on the controller, which is possible after redesigning the aerodynamic drive transmission gears. Changing of the tiller's handle would be an operation that would improve the pilot's comfort, even if it wouldn't reduce the assessment result itself. At present the pilot is forced to use much strength for change the tiller's handle from a slippery ball on the oblong handle that is shaped in a way to not hamper movement while getting out of the cabin. Modernization is in this case necessary because it causes risk in critical phases of the flight, i.e. during the takeoff and the landing. During the takeoff, when the glider is behind the plane and flies with circa $120 \mathrm{~km} / \mathrm{h}$ (a speed that cannot be reduced promptly without resealing the glider from the plane) and in the same time it is affected by the helicopter braid of the plane that drags it, brakes are often being "sucked out". The occurrence of significant forces on the controller and the uncomfortable gear make closing the brake almost impossible. Pilots face similar problems while their attempt to tense the rope while the glider is towed and they try opening the brakes. During the landing the pilot also often cannot close the brakes in view to strong forces (especially when the pilot is not experienced, those who have more experience know how to manage by reducing the speed). Presented situations are connected with the inability of closing brakes and they often finished with accidents. Steering the aerodynamic brakes while preparations to the landing is another aspect. This operation requires much force and it is difficult to perform this operation with precise, fluent, controlled movements both with brakes and with other controllers. This affects the construction of the correct profile during the landing, and this affect the security. It is worth to mention that there are significant differences in values of forces that occur on individual gliders. It is caused in some part by the correct use. It is often possible to reduce forces by appropriate smearing elements transferring the drive.

The elaboration presented different suggestions for improving the ergonomics of the cabin of the glider SZD-30 "Pirat". Some of them are difficult to apply view to high costs and view to the fact that the majority of glider's time for use has expired a long time ago. 
Still, there is a possibility of implementing many small modification that would not require high costs and wouldn't interfere the construction much. These are changes like: changing gears of controllers, using better shaped seats or installing a better support between the pilot's back and the parachute.

\section{Summary}

The purpose of examinations was to asses loads of the motor system, as an aspect of the ergonomic risk. Basing on conduced research and results obtained with use of the RULA method, there has been made an assessment of the work of a pilot, view to the ergonomic aspect. Taking under consideration available standards, one examined risks of the occurrence of ailments and diseases in the muscular and skeleton system while performing operations during the flight, as well as causes of unnatural positions that the pilot must do.

Research results showed that the work of a pilot in a glider SZD 30 "Pirat" is dangerous and it gives risk of numerous ailments. On this basis one has stated that it is necessary to implement preventive actions for reducing the number of risks connected with this work. One has suggested some corrective actions for improving the existing situation. Suggestions concern not only the risk for ailments that the pilot faces, but also they should improve the safety of flights. It is necessary to design operation in consultations with pilots. One should take under consideration the fact that flights in gliders, especially of such type of constructions, are long lasting, and the pilot is exposed to many other factors that strengthen the impact given by unnatural positions. The acceleration affecting the pilot is one of crucial factors. During the circulation, which takes the majority of time of the thermal flight, the pilot experiences the overload of $1.5 \mathrm{G}$. It has a significant impact on him during the $5 \mathrm{~h}$ flight. Moreover, the pilot is exposed to many other factors that cumulated with an unnatural position overload him even more. These are factors like: changing temperature, air pressure and humidity, insolation, noise and vibrations. In the same time one should remember about the stress, high information load and low margin for mistakes. Constructors of such crafts should focus on the ergonomics of such planes. It is difficult view to the realization of construction assumptions they have made, especially in designing gliders, where it is important to obtain high aerodynamic results and where the cabin is adjusted to the rest of the construction instead of being designed for the comfort of the pilot from the start.

In result of this compromise is that the pilot must work in difficult environment, unadjusted to his anthropometric characteristics.

One should perceive ergonomics in aircrafts cabins not only from the point of view of the comfort, but also because of the safety of performed operations. In the process of performed examination it occurred to be surprising that despite almost 50 years of exploitation of this type of glider (the production started in 1966) and despite many signals from groups involved in this activity, the construction wasn't changed, even in such small ranges, like presented suggestions of simple modifications for improving the ergonomics of the machine. 
The idea of modification of work conditions for the reduction of the pilot's... Koncepcja modyfikacji warunków pracy zmniejszajacych obciażenia pilota...

\section{Literature}

[1] Dahlke G., Sasim J., Sasim B., Analiza biomechaniczna obciążenia pilota samolotu M-28 Bryza, Logistyka 5/2014

[2] www.osha.europa.pl

[3] Galant M., Analysis of the possibilities of using EEG in assessing pilot's psychophysical condition, Scientific Journal of Silesian University of Technology. Series Transport, 95, p.39-46

[4] Sławińska M., Niezawodność człowieka w interakcji $\mathrm{z}$ procesem przemysłowym, Wyd. Politechniki Poznańskiej, Poznań 2012, p. 30-31

[5] Śmiełkiewicz J., Problemy rozwoju szybowca SZD-30 PIRAT, Polska Technika Lotnicza Materiały Historyczne 17 (10/2005)

[6] Państwowa Komisja Badania Wypadków Lotniczych, Raport końcowy zdarzenie nr 293/07, Warszawa 2008

[7] Horst W., Ryzyko zawodowe na stanowisku pracy. Część I Ergonomiczne czynniki ryzyka, Wyd. Politechniki Poznańskie, Poznań 2004.

[8] Jasiak A. Porównanie jakości ergonomicznej i oceny ryzyka zawodowego na przykładzie wiertarki stołowej, Zeszyty Naukowe Politechniki Poznańskiej, Organizacja i Zarządzanie, Nr 61, Poznań 2013

[9] www.personal.health.usf.edu

[10] User manual for glider flights in SZD-30 "Pirat"
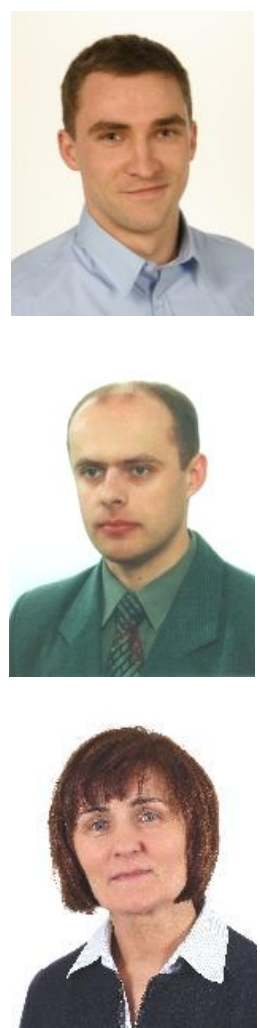

M.Sc. Eng. Marcin Berlik, Ph.D student of the Faculty of Engineering Management of the Poznan University of Technology. He obtained his engineer degree in the field of Safety Engineering and the master degree in a field of the Air Transport. A pilot, instructor of glider flights. His scientific interests focus on safety of flights with special attention on issues related to the ergonomics and the human factor (Share 50\%).

Ph.D. Eng. Grzegorz Dahlke, employee of Poznan University of Technology, Chair of Ergonomics and Quality Engineering. Head of the Laboratory of Ergonomics and Occupational Risk. Since 2010, ergonomic cavitations have been certified by Center for Registration of European Ergonomists. Author of over 100 scientific publications in the field of ergonomics, work safety and safety management systems (Share 30\%).

Assoc. Eng. Malgorzata Stawińska, employee of Poznan University of Technology, Chair of Ergonomics and Quality Engineering, an expert in the fields: usability of technical systems, formal methods of description and optimization of the processes of interaction in a human-technical subsystem, diagnosis and design of an ergonomic workplaces (Share 20\%). 


\section{KONCEPCJA MODYFIKACJI WARUNKÓW PRACY ZMNIEJSZAJĄCYCH OBCIĄŻENIA PILOTA SZYBOWCA TYPU SZD-30}

\section{Wstęp}

Projektowanie stanowisk pracy $\mathrm{z}$ wiedzą o możliwościach psychofizycznych człowieka przyczynia się do obniżenia ryzyka występowania przeciążenia zadaniami, np. dolegliwościami narządu ruchu pracownika i w konsekwencji zawodnością tych zadań i mniejszym prawdopodobieństwem zaistnienia wypadku.

Pozycja przyjmowana przez pracownika podczas pracy może przyczynić się do powstania zdarzeń wypadkowych oraz do wystapienia u pracownika symptomów i objawów chorobowych narządu ruchu [1], [2].

Wśród czynników ryzyka ergonomicznego generujących wystąpienie dolegliwości narządu ruchu możemy zaliczyć:

- pracę, która wymaga utrzymywania pozycji wymuszonych,

- pracę wymagającą częstego podnoszenia, pchania, ciągnięcia lub ręcznego przemieszczania obiektów o dużej masie,

- długotrwałego, powtarzalnego oraz dużego wysiłku rąk,

- narażenie na drgania,

- narażenie na chłód [1].

Ważne jest świadome projektowanie techniki uwzględniając powyższe czynniki w taki sposób, aby człowiek narażony był na jak najmniejsze obciążenie. Obiektem użytkowania obiektu technicznego uwzględniając przyjmowaną pozycję ciała, technicznym, w odniesieniu do którego zaobserwowano grupę istotnych czynników przeciążenia jest szybowiec typu SZD-30 "Pirat". $\mathrm{Z}$ osobistego doświadczenia badacza i obserwacji podczas eksperymentów wiadomo, że praca pilota wymaga dużej koncentracji uwagi, zwinności uwagi, kontroli wielu parametrów jednocześnie, szybkiego podejmowania decyzji oraz precyzji ruchów sterownicami, co składa się na tzw. obciążenie systemowe [1], [3], [4]. Na sposób użytkowania urządzeń technicznych decydujący wpływ ma przede wszystkim konstrukcja elementów technicznych.

Szybowiec typu SZD-30 "Pirat" jest jednomiejscowym szybowcem drewnianym w układzie górnopłata. Konstrukcja pochodzi z początku lat 70tych $\mathrm{XX}$ w. W zamyśle producenta typ ten miał tymczasowo zasilić flotę Aeroklubu Polskiego, jednak wciąż stanowi on jeden $\mathrm{z}$ podstawowych szybowców służących do treningu mniej doświadczonych pilotów w długich lotach termicznych oraz wykonywania pierwszych przelotów. [5].

Wśród instruktorów Pirat cieszy się opinią szybowca niebezpiecznego ze względu na problemy z ergonomią. Również Państwowa Komisja Badania Wypadków Lotniczych w raportach końcowych wypadków oraz incydentów podaje, jako jedną z przyczyn problemy ergonomii szybowca.

Wśród głównych problemów wymienia się dysproporcje sił występujących na sterach (do wychylenia powierzchni sterowej o daną wartość wymagana jest diametralnie inna siła dla każdego steru) oraz analogicznie proporcje wychyleń (np. wychylenie lotki generuje niewielką prędkość kątową zmiany przechylenia, podczas gdy takie samo wychylenie steru wysokości na drążku generuje dużo większą prędkość kątową zmiany pochylenia). 
The idea of modification of work conditions for the reduction of the pilot's...

Koncepcja modyfikacji warunków pracy zmniejszajacych obciażenia pilota...

Ponadto na dźwigni hamulca aerodynamicznego występują bardzo duże siły, które często uniemożliwiały (szczególnie słabszym fizycznie pilotom oraz przy większych prędkościach) zamknięcie ich. Przyłożenie znacznej siły na powyższą sterownicę może mieć wpływ także umieszczenie hamulca oraz ksztalt uchwytu. O tych trzech mankamentach informuje Instrukcja Użytkowania w Locie (IUL), jednak nie wprowadzono modyfikacji, które w sposób znaczący niwelowałyby niedogodności [6].



Fot. 1 Widok wnętrza kabiny szybowca SZD-30 „Pirat” podczas lotu (Źródto: fotografia wtasna).

Nienaturalna pozycja ciała ma duży wpływ na zmęczenie lotem, jakość wykonywanych czynności przez dowódcę statku powietrznego oraz właściwą pracę sterownicami. Niniejsza praca koncentruje się na zbadaniu ryzyka ergonomicznego pilota szybowca tego typu.

\section{Ocena ryzyka ergonomicznego}

Istnieje wiele metod oceny ryzyka, które różnią się stopniem skomplikowania oraz zastosowaniem. Istotny jest odpowiedni dobór metody. Najczęściej wykorzystywanymi metodami identyfikacji biomechanicznych czynników ryzyka są [7]:

- ankiety i wywiady z pracownikami,

- audyty,

- eksperckie metody kontrolne,

- analityczne metody pomiarowe oparte na obserwacji (bezpośredniej i pośredniej),

- pomiary bezpośrednie stresu mechanicznego,

- modelowanie (doświadczalne lub teoretyczno-doświadczalne).

Rapid Upper Limb Assessment (RULA) jest metodą pomiaru obciążenia posturalnego oraz czynnościowego kończyn górnych, które występuje podczas wykonywania czynności w pozycji siedzącej. 


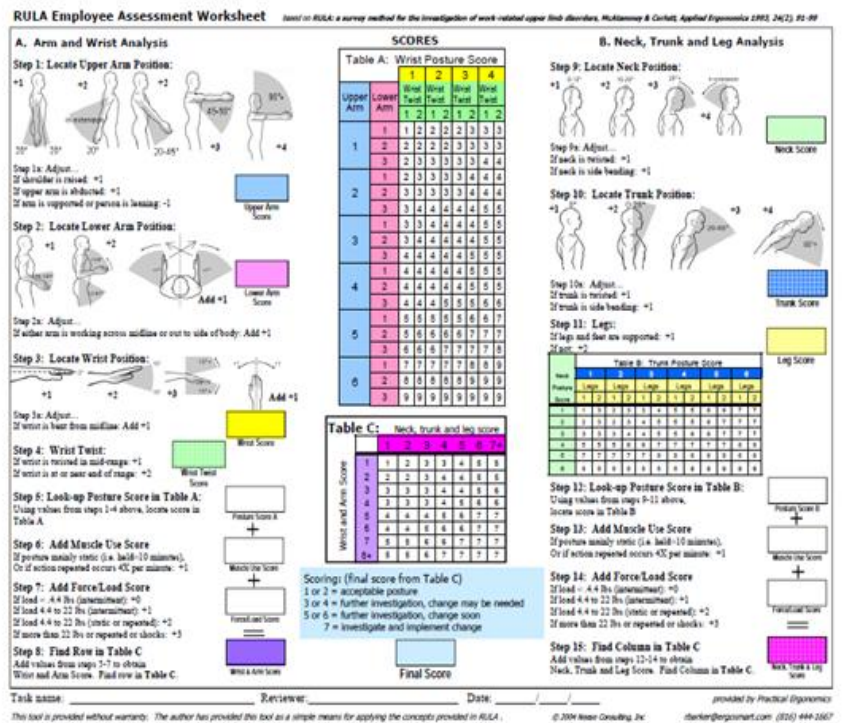

Rys. 1 Kwestionariusz dla metody RULA [9].

Metoda RULA oszacować ryzyko dolegliwości i schorzeń układu ruchu wywołanych sposobem wykonywania pracy.

\section{Charakterystyka statku powietrznego [10]}

Badania przeprowadzono na szybowcu typu SZD-30 "Pirat" o znakach SP2741, którego użytkownikiem jest Centralna Szkoła Szybowcowa Aeroklubu Polskiego w Lesznie.

Szybowiec typu SZD-30 "Pirat" jest jednomiejscowym szybowcem treningowym. Pierwotnie był on dopuszczony do wykonywania akrobacji.

Kabina mieści wygodnie pilota do $2 \mathrm{~m}$ wzrostu, ze spadochronem plecowym. Przed zajęciem miejsca $\mathrm{w}$ kabinie należy odpowiednio do wzrostu i ciężaru ustawić oparcie spadochronu.

Położenie pedałów można zmienić przed lotem oraz w trakcie jego trwania. Pilot przypięty pasami powinien mieć możliwość wykonania pełnych wychyleń drążka i pedałów oraz swobodny zasięg ręki do tablicy przyrządów.

\section{Wyniki badań wykonanych przy pomocy metody RULA}

Metoda RULA metodą pomiaru obciążenia posturalnego oraz czynnościowego kończyn górnych, które występuje podczas wykonywania czynności w pozycji siedzącej. Pozwala ona oszacować ryzyko dolegliwości i schorzeń układu ruchu wywołanych sposobem wykonywania pracy [8].

Podczas lotu pilot szybowca wykonuje wiele czynności, które mają bardzo duży wpływ na bezpieczeństwo wykonywanych operacji lotniczych. Wykonywanie każdej czynności powoduje zmianę pozycji pilota, a co za tym idzie generuje ono zmianę obciążenia układu mięśniowo-szkieletowego.

$\mathrm{W}$ badaniach przeprowadzonych $\mathrm{w}$ kabinie szybowca uwzględniono 15 czynności wykonywanych przez pilota lewą i prawą ręką w trakcie trwania lotu. Wybrane czynności przedstawiono w tabeli nr 1. 
The idea of modification of work conditions for the reduction of the pilot's...

Koncepcja modyfikacji warunków pracy zmniejszajacych obciażenia pilota...

Tab. 1 Zestawienie wybranych czynności wykonywanych przez pilota szybowca, bedacych przedmiotem analizy (Źródto: opracowanie wlasne, fotografie autora).

\begin{tabular}{|c|c|c|c|}
\hline L.p. & $\begin{array}{l}\text { Nazwa czynności } \\
\text { realizowanej przez }\end{array}$ & $\begin{array}{l}\text { Widok } 1 \\
\text { (z boku) }\end{array}$ & $\begin{array}{l}\text { Widok } 2 \\
\text { (z góry) }\end{array}$ \\
\hline 1 & $\begin{array}{l}\text { Ster wysokości } \\
\text { "od siebie", } \\
\text { lotki w lewo }\end{array}$ & & \\
\hline 2 & $\begin{array}{l}\text { Ster wysokości } \\
\text { "na siebie", } \\
\text { lotki w lewo }\end{array}$ & & \\
\hline 3 & $\begin{array}{l}\text { Ster wysokości } \\
\text { "na siebie", } \\
\text { lotki w prawo }\end{array}$ & & \\
\hline 4 & $\begin{array}{c}\text { Hamulce } \\
\text { aerodynamiczne } \\
\text { otwarte }\end{array}$ & & \\
\hline 5 & $\begin{array}{c}\text { Trymer } \\
\text { "ciężki na ogon" }\end{array}$ & & \\
\hline 6 & $\begin{array}{l}\text { Pozycja neutralna } \\
\text { (stery w neutrum, } \\
\text { lewa ręka oparta na } \\
\text { kolanie - stan } \\
\text { czuwania) }\end{array}$ & & \\
\hline
\end{tabular}


Marcin Berlik, Grzegorz Dahlke, Małgorzata Stawińska

Tab. 2 Zestawienie ocen końcowych wg. metody RULA dla przebadanych czynności (Źródto: opracowanie własne)

\begin{tabular}{|c|c|c|}
\hline L.p. & Czynność & $\begin{array}{c}\text { Ocena } \\
\text { końcowa } \\
\text { według RULA }\end{array}$ \\
\hline 1 & Pozycja neutralna & 4 \\
\hline 2 & Wyczepienie liny & 4 \\
\hline 3 & Ster wysokości “od siebie”, lotki w neutrum & 4 \\
\hline 4 & Lotki w lewo, ster wysokości w neutrum & 4 \\
\hline 5 & Lotki w prawo, ster wysokości w neutrum & 5 \\
\hline 6 & Ster wysokości "od siebie”, lotki w lewo & 5 \\
\hline 7 & Ster wysokości “od siebie”, lotki w prawo & 4 \\
\hline 8 & Ster wysokości "na siebie”, lotki w lewo & 6 \\
\hline 9 & Ster wysokości "na siebie", lotki w prawo & 6 \\
\hline 10 & Hamulce aerodynamiczne zamknięte & 6 \\
\hline 11 & Hamulce aerodynamiczne otwarte & 6 \\
\hline 12 & Trymer "ciężki na łeb" & 5 \\
\hline 13 & Trymer "ciężki na ogon" & 5 \\
\hline 14 & Obsługa radiostacji & 5 \\
\hline 15 & Obsługa wywietrznika & 5 \\
\hline
\end{tabular}

Tab. 3 Skala ocen dla metody RULA

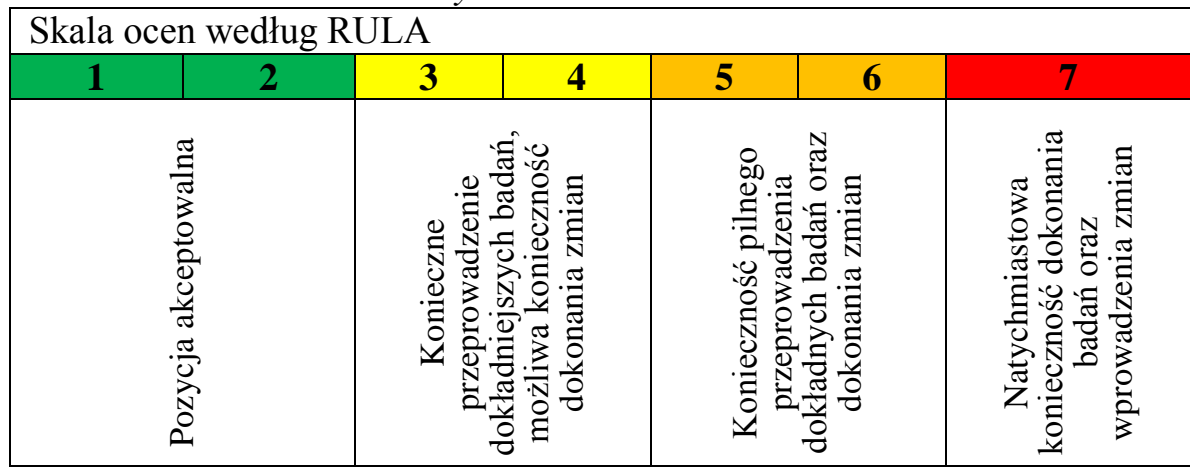

Wyniki dla zbadanych 15 czynności oscylują w zakresie od 4 do 6 . Stosunkowo niewielki zakres wartości wynika $\mathrm{z}$ faktu, iż pilot zajmując pozycję $\mathrm{w}$ kabinie posiada $\mathrm{w}$ dużej mierze unieruchomiony tułów (przypięty pasami piersiowymi oraz biodrowymi), co jednocześnie $\mathrm{w}$ znacznie sposób determinuje stałe pozycje szyi i głowy. Najwięcej zmian pozycji dotyczy ramion, przedramion, oraz nadgarstka i nie są one $\mathrm{w}$ stanie $\mathrm{w}$ aż tak diametralny sposób zróżnicować ocen. Wartości w zakresie od 4 do 6 są dużymi wartości, które powinny wzmóc czujność każdego audytora.

Dla pięciu czynności ocena wynosi 4, co oznacza, że konieczne jest przeprowadzenie dokładniejszych badań oraz możliwa jest konieczność dokonania zmian. 
The idea of modification of work conditions for the reduction of the pilot's... Koncepcja modyfikacji warunków pracy zmniejszajacych obciażenia pilota...

Są to pozycje zbliżone do pozycji neutralnej (drążek w neutrum, lewa ręka oparta na kolanie). Ułożenie ręki na kolanie w pozycji neutralnej nie wynika $\mathrm{z}$ wygody pilota, a jest wpajane od początku przez cały proces szkolenia. Ma to na celu łatwy i szybki dostęp do wszystkich sterownic oraz ma uniemożliwić przypadkowe przesunięcie którejkolwiek sterownicy w przypadku przyspieszenia działającego na szybowiec w jakimkolwiek kierunku, co miewa miejsce podczas częstej, aczkolwiek nieprawidłowej praktyki opierania ręki na dźwigni hamulca aerodynamicznego. Najniższy wynik dla pozycji neutralnej świadczyć może o tym, iż najtrudniejsze do uzyskania są pozycje skrajne sterownic we wszystkich kierunkach (zarówno znajdujące się daleko, jak i te blisko).

Wynik oceny metodą RULA równy jest 5 dla sześciu czynności. Świadczy on o konieczności pilnego przeprowadzenia dokładnych badań oraz dokonania zmian. W przypadku obsługi trymera wyższa wartość wynika przede wszystkim z potrzeby jednoczesnego zgięcia oraz skręcenia nadgarstka. W tym przypadku prostym rozwiązaniem może być modyfikacja uchwytu np. o podłużnym kształcie poprowadzonego w osi pionowej w dół, tak, aby ułatwić chwytanie, a nie utrudniać wsiadania i wysiadania z szybowca, szczególnie awaryjnego upuszczania kabiny. Także czynności związane $\mathrm{z}$ obsługą radiostacji oraz wywietrznika uzyskały wynik 5 . Jest to także spowodowane skręceniami oraz zgięciami nadgarstka, które powoduje rozmieszczenie manipulatora radiostacji oraz wywietrznika nie $\mathrm{w}$ osi wyciągniętego ramienia pilota (szczególnie obsługa wywietrznika, gdzie należy dokonać przesunięcia dźwigni w osi znajdującej się pod kątem ok. 45 stopni do osi ramienia). Pozostałe dwa wyniki 5 dla czynności "Ster wysokości "od siebie", lotki w lewo" oraz "Lotki w prawo, ster wysokości w neutrum" wynikają przede wszystkim z przykładania siły podczas wychylania lotki. Są to jednocześnie najniższe oceny dla czynności zawierających wychylenie lotki, wynika to m.in. z pozycji drążka, które nie wymagają skręceń i zgięć nadgarstka.

Najwyższy wynik - 6 osiągnęly 4 pozycje. Świadczy on o konieczności pilnego przeprowadzenia dokładnych badań oraz dokonania zmian. Jest to wynik bardzo wysoki. Przyczyny przyjęcia tak wysokich wartości są dwojakie. Dla czynności "Ster wysokości "na siebie", lotki w lewo" oraz "Ster wysokości "na siebie", lotki w prawo" występują bardzo duże zgięcia oraz skręcenia. Wynika to z wychylenia drążka maksymalnie na siebie, przy którym pilot musi przyciągnąć drążek bardzo blisko tułowia.

Po stronie prawej drążek musi się znaleźć tuż przy jego biodrze, co przy jednocześnie ograniczonej przestrzeni (niemożność wycofania ramienia) wymaga zgięcia i skręceń nadgarstka. Po stronie lewej natomiast pilot zmuszony jest umieścić drążek przy lewym biodrze, co wymaga przywiedzenia kończyny górnej, zgięć przedramienia, nadgarstka oraz jego skręceń (wielu pilotów, szczególnie tęższych, czy cieplej ubranych zmuszonych jest ominąć kończyną górną brzuch oraz klamrę pasów, co dodatkowo generuje przyjmowanie przez kończynę górną nienaturalnych pozycji). 
Problemem występującym u zdecydowanej części pilotów jest niemożność osiągnięcia pełnego wychylenia na siebie $\mathrm{i}$ w bok, nie tylko ze względu na możliwości kończyn górnych, ale przez blokowanie drążka przez uda.

Powyższe problemy świadczą o umieszczeniu drążka zbyt blisko pilota. Jednocześnie jest ono w obecnej sytuacji konieczne dla zapewnienia pełnych wychyleń na boki i w przód. Rozwiązaniem problemu może być wcześniej wspomniane skrócenie drążka (wymagające jednocześnie redukcji sił na nim występujących przez przeprojektowanie przekładni w napędach lotek oraz steru wysokości).

Wynik 6 osiągają także pozycje związane $\mathrm{z}$ obsługą dźwigni hamulca aerodynamicznego. $\mathrm{W}$ tym przypadku czynnikiem mającym duży wpływ na wysoki wynik oceny jest duża siła niezbędna do obsługi hamulca aerodynamicznego. Poza położeniami, w których hamulec jest zablokowany, utrzymanie go w żądanej pozycji wymaga użycia dużej siły. Jest to spowodowane efektem "wysysania" płyt hamulca aerodynamicznego z płata, co jest przenoszone napędem hamulca na sterownicę znajdującą się w kabinie. Najważniejszym działaniem korygującym jest zmniejszenie siły występującej na sterownicy poprzez zmodyfikowanie przekładni napędu hamulca aerodynamicznego. Działaniem, które być może nie przyczyniłoby się do zmniejszenia wartości oceny, ale na pewno wpłynęłoby na wygodę pilota jest zmiana uchwytu sterownicy. Pilot zmuszony jest przykładać dużą siłę do jej zmiany z śliskiej kulki na podłużny uchwyt mieszczący całą rękę pilota, skierowany ku górze tak, aby nie utrudniać opuszczania kabiny. Modernizacja w tym zakresie jest konieczna, ponieważ zagraża przede wszystkim w krytycznych fazach lotu, jakimi jest start i lądowanie. Podczas startu za samolotem, gdy szybowiec holowany jest z prędkością ok $120 \mathrm{~km} / \mathrm{h}$ (której nie można gwałtownie zmniejszyć bez wyczepienia się) jednocześnie pod wpływem działania "warkocza zaśmigłowego" statku holującego, płyty hamulca aerodynamicznego często są wysysane. Występowanie dużych sił na sterownicy oraz niewygodny uchwyt sprawia, że zamknięcie hamulca w takich warunkach dla słabszych fizycznie pilotów staje się wręcz niemożliwe.

Podobny problem występuje przy próbach naprężenia zluzowanej liny podczas holu za samolotem poprzez otwarcie hamulców. Również podczas lądowania pilot często nie może zamknąć hamulców ze względu na zbyt duże siły (szczególnie mniej doświadczony, doświadczeni piloci zazwyczaj pomagają sobie redukując prędkość). Powyższe sytuacje związane $\mathrm{z}$ niemożnością zamknięcia hamulców niejednokrotnie skutkowały wypadkami lub incydentami lotniczymi. Kolejnym aspektem jest sterowanie hamulcami aerodynamicznymi podczas podejścia do lądowania. 
The idea of modification of work conditions for the reduction of the pilot's... Koncepcja modyfikacji warunków pracy zmniejszajacych obciażenia pilota...

Potrzeba stosowania dużych sił utrudnia wykonywanie płynnych, kontrolowanych, precyzyjnych ruchów zarówno hamulcami jak i innymi sterownicami (drążkiem, pedałami). Odbija się to na budowie prawidłowego profilu do lądowania, co przekłada się jednocześnie na jego bezpieczeństwo. Warto nadmienić, iż występują duże różnice w wartościach sił występujących na poszczególnych egzemplarzach szybowca. Ma na to pewien wpływ prawidłowa eksploatacja. Często można zredukować siły poprzez prawidłowe smarowanie elementów przenoszących napęd.

Powyżej podano różne propozycje działań korygujących, mających na celu poprawę ergonomiczności kabiny szybowca SZD-30 "Pirat". Niektóre z nich są trudne do wdrożenia ze względu na duże koszty oraz fakt, iż znacząca część planowanego okresu eksploatacji już upłynęła. Istnieje natomiast możliwość wprowadzania wielu wręcz kosmetycznych modyfikacji, które nie pociągają za sobą wysokich kosztów oraz nie ingerują w sposób znaczący w konstrukcję szybowca. Należą do nich między innymi wymiana uchwytów, czy montaż nowych, odpowiednio ukształtowanych misek siedzeniowych, czy bardzo doraźna forma redukcji wypukłości kręgosłupa poprzez zastosowanie specjalnej poduszki umieszczanej pomiędzy spadochronem, a plecami pilota.

\section{Podsumowanie}

Celem badań była ocena obciążeń układu ruchu, jako wybranego aspektu ryzyka ergonomicznego. Na podstawie wykonanych badań oraz opracowanych wyników przy metody RULA dokonano oceny pozycji pracy pilota pod względem ergonomicznym. Uwzględniając dostępne normy sprawdzono wielkość zagrożeń powodujących dolegliwości mięśniowo-szkieletowych podczas wykonywania czynności w locie przez pilota oraz przyczyny przyjmowania nienaturalnych pozycji.

Wyniki badań wykazały, iż praca pilota szybowca typu SZD 30 "Pirat" jest niebezpieczna oraz naraża go na szereg dolegliwości. Na tej podstawie stwierdzono konieczność wdrożenia działań prewencyjnych $\mathrm{w}$ celu zmniejszenia liczby zagrożeń związanych ze sposobem wykonywania pracy.

Zaproponowano niektóre działania korygujące mające na celu poprawę stanu istniejącego. Propozycje działań uwzględniają nie tylko narażenie pilota na dolegliwości mięśniowo-szkieletowe, ale także ogólne bezpieczeństwo lotów.

Nieodzowne w projektowaniu działań są konsultacje z pilotami. Należy uwzględnić to, iż loty szybowcowe, szczególnie na konstrukcjach o tego typu przeznaczeniu są długotrwałe, a pilot narażony jest na wiele innych czynników, które potęgują oddziaływanie nienaturalnej pozycji. Podstawowym z nich są przyspieszenia działające na pilota. 
Podczas krążenia w kominie, które pochłania większość czasu lotu termicznego (długotrwałego) na pilota działa przeciążenie rzędu 1,5 G, co nie pozostaje bez znaczenia podczas pięciogodzinnego lotu. Ponadto pilot narażony jest na wiele innych czynników, które po skumulowaniu z utrzymywaniem nienaturalnej pozycji jeszcze bardziej obciążają człowieka. Do tych czynników należą m.in. wahania temperatury, ciśnienia i wilgotności powietrza, silne nasłonecznienie, hałas, drgania. Jednocześnie pamiętając o dużym stresie, obciążeniu informacyjnym oraz niewielkim marginesie błędu konstruktorzy powinni wyjątkowo dużą uwagę koncentrować na ergonomii statków powietrznych. Jest to trudne zważając na realizacje założeń konstrukcyjnych. Szczególnie w projektowaniu szybowców bardzo istotne są osiągi płatowca, dlatego kabina jest niejako dopasowywana do całej konstrukcja, a nie projektowana od początku z myślą o pilocie.

Efektem tego kompromisu są często dodatkowo utrudnione warunki pracy pilota spowodowane niedostosowaniem obiektu technicznego do jego cech antropometrycznych.

Należy postrzegać ergonomię kabin statków powietrznych nie tylko ze względu na wygodę, ale przede wszystkim ze względu na bezpieczeństwo wykonywanych operacji. Podczas procesu realizacji badań zaskakujący wydał się fakt, że pomimo tak długiego 50 letniego okresu eksploatacji tego typu szybowca (produkcję rozpoczęto w roku 1966) oraz wielu sygnałów ze strony środowiska lotniczego konstrukcja nie doczekała się choćby wielu prostych i tanich modernizacji mających na celu poprawę ergonomiczności.

\section{Literatura}

[1] Dahlke G., Sasim J., Sasim B., Analiza biomechaniczna obciążenia pilota samolotu M-28 Bryza, Logistyka 5/2014

[2] www.osha.europa.pl

[3] Galant M., Analysis of the possibilities of using EEG in assessing pilot's psychophysical condition, Scientific Journal of Silesian University of Technology. Series Transport, 95, s.39-46

[4] Sławińska M., Niezawodność człowieka w interakcji z procesem przemysłowym, Wyd. Politechniki Poznańskiej, Poznań 2012, s. 30-31

[5] Śmiełkiewicz J., Problemy rozwoju szybowca SZD-30 PIRAT, Polska Technika Lotnicza Materiały Historyczne 17 (10/2005)

[6] Państwowa Komisja Badania Wypadków Lotniczych, Raport końcowy zdarzenie nr 293/07, Warszawa 2008

[7] Horst W., Ryzyko zawodowe na stanowisku pracy. Część I Ergonomiczne czynniki ryzyka, Wyd. Politechniki Poznańskie, Poznań 2004. 
The idea of modification of work conditions for the reduction of the pilot's...

Koncepcja modyfikacji warunków pracy zmniejszajacych obciażenia pilota...

[8] Jasiak A. Porównanie jakości ergonomicznej i oceny ryzyka zawodowego na przykładzie wiertarki stołowej, Zeszyty Naukowe Politechniki Poznańskiej, Organizacja i Zarządzanie, Nr 61, Poznań 2013

[9] www.personal.health.usf.edu

[10] Instrukcja użytkowania w locie szybowca SZD-30 "Pirat"

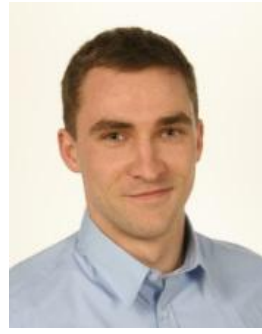

mgr inz. Marcin Berlik, doktorant Wydziału Inżynierii Zarzadzania Politechniki Poznańskiej. Ukończyt studia inżynierskie na kierunku Inżynieria bezpieczeństwa oraz magisterskie na specjalności Transport lotniczy. Pilot, instruktor szybowcowy. Zainteresowania naukowe obejmuja szeroko pojęte bezpieczeństwo lotów ze szczególnym uwzględnieniem zagadnień zwiazanych $z$ ergonomia i czynnikiem ludzkim (Udział 50\%).

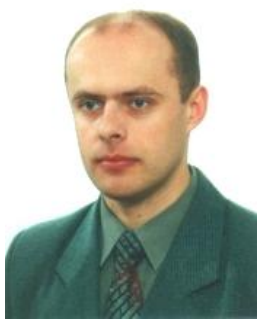

dr inj. Grzegorz Dahlke, pracownik Politechniki Poznańskiej, Katedry Ergonomii $i$ Inżynierii Jakości. Kierownik Laboratorium Ergonomii i Ryzyka Zawodowego. Od roku 2010 kawlifikacje ergonomiczne zostaty certyfikowane przez CREE. Autor ponad 100 publikacji naukowych $z$ zakresu ergonomii, bezpieczeństwa pracy i systemów zarzadzania bezpieczeństwem (Udział 30\%).

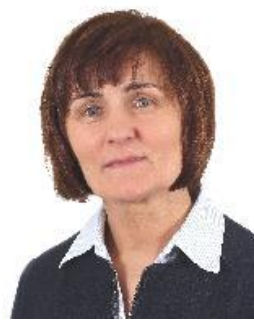

dr hab. inż. Matgorzata Stawińska, pracownik Politechniki Poznańskiej, Katedry Ergonomii $i$ Inżynierii Jakości, specjalista $w$ zakresie użyteczności systemów informatycznych, formalnych metody opisu $i$ optymalizacji procesu interakcji w uktadzie czlowiek-obiekt techniczny oraz diagnozowania $i$ projektowania ergonomicznego miejsca pracy (Udziat 20\%). 